\title{
Liette Gidlow
}

\section{THE SEQUEL: THE FIFTEENTH AMENDMENT, THE NINETEENTH AMENDMENT, AND SOUTHERN BLACK WOMEN'S STRUGGLE TO VOTE}

This essay reframes both the woman suffrage narrative and narratives of African American voting rights struggles by focusing on the experiences of southern African American women between the 1870s and the 1920s. It argues that the Fifteenth Amendment remained central to their suffrage strategy long after the failure of the "New Departure" to win court sanction caused white suffragists to abandon it. As white supremacists in the South worked at the turn of the century to disfranchise black men, leading African American suffragists such as Mary Church Terrell, Gertrude Bustill Mossell, and Adella Hunt Logan called for the enforcement of the Fourteenth and Fifteenth Amendments as well as the enfranchisement of black women. After the federal woman suffrage amendment was ratified in 1920, many southern African American women encountered the same barriers to voting - obstructionist tactics, threats, and violence-that black men had faced a generation earlier. In short, for aspiring African American voters in the South, the failure of the Nineteenth Amendment to secure voting rights for black women constituted a sad sequel to the failure of the Fifteenth Amendment to secure voting rights for black men.

This interpretation offers three significant interventions. It pairs the Reconstruction-era Amendments with the Nineteenth Amendment, recognizing their shared focus on voting rights. It connects the voting rights struggles of southern African Americans across genders and generations. Finally, it finds that, for some women, the canonical "century of struggle" for voting rights continued long after the Nineteenth Amendment was ratified.

Lula Murry knew her rights. After the Jefferson County, Alabama Board of Registrars rejected her voter registration application in the fall of 1923, Murry, a woman in her fifties whose roots reached back to Georgia and whose husband made a steady living as a mattress maker, took the problem straight to President Calvin Coolidge. Her family had fulfilled its obligations to the nation; she expected the federal government to fulfill its obligations to her. Two of her brothers had answered the nation's call to military service in its "time of ... Greatest necessity," she wrote, one giving his life "in the defense cause in [the] time known as the world war to elevate to safe democracy." Her complaint? That, in Birmingham, "safe democracy" was nowhere to be found. "Here I stand denied the constitution rights in Article XIV and XV ... [and] I being a woman[,] the 19th Amendment of the Constitution of U.S." Murry was as fearless as she was firm. In Jim Crow Alabama, she wrote her name and return address on the envelope and sent the letter by registered mail. ${ }^{1}$ 
Like many American women in the early years after the 1920 ratification of the Nineteenth Amendment, Lula Murry found that she still could not vote. ${ }^{2}$ Like many African Americans of her day, she connected the success or failure of the Nineteenth Amendment in securing voting rights for African American women to the history of the Fourteenth and especially the Fifteenth Amendments in the years after Reconstruction. The Fourteenth Amendment, ratified in 1868, established that African Americans were citizens and, for the first time, expressly protected voting rights for adult male citizens. Two years later, the Fifteenth Amendment proclaimed that the "right of citizens of the United States to vote shall not be denied or abridged by the United States or by any state on account of race, color, or previous condition of servitude." Backed by these amendments, in the living memory of many of her contemporaries and quite possibly within her own, vast multitudes of African American men in the South had in fact voted in elections supervised by the U.S. military and then in the reconstructed states. Black men's turnout peaked at perhaps 90 percent in elections to call conventions to write new state constitutions, select convention delegates, and fill local, state, and federal offices. ${ }^{3}$

In the decades after federal troops withdrew from the South, however, the number of African American men who voted in the region dwindled. The Supreme Court gutted the Fourteenth and Fifteenth Amendments with decisions in the Slaughterhouse Cases and Cruikshank, giving opponents of black voting more legal room to maneuver. White supremacists rendered black men's votes moot through fraud and drove them from the polls with campaigns of intimidation and bloody violence. States erected new procedural barriers to the ballot such as cumulative poll taxes and erstwhile "literacy" tests. And finally, in a period between 1890 and 1908 that historian Michael Perman calls "Restoration," southern states, starting with Mississippi in 1890 and concluding with Georgia in 1908, worked to settle the "race question" once and for all by enshrining disfranchising measures in new or amended state constitutions. By the end of the first decade of the twentieth century, only a few African American men, often a community's so-called "best men," retained voting rights. Many African Americans, Lula Murry among them, recognized that the Nineteenth Amendment was erected atop the rickety ruins of the Fourteenth and Fifteenth Amendments. Between the turn of the century and the 1920s, African American woman suffragists were determined to hold the nation accountable for all three amendments. ${ }^{4}$

By pairing the Reconstruction-era amendments with the Nineteenth Amendment, Murry and like-minded contemporaries saw connections-between generations, between races, and between women and men-that scholars of voting rights and women's rights have yet to fully explore. It took decades for the verdict on the effectiveness of the Fifteenth Amendment to become clear. By thinking intersectionally across what historian Nancy Cott called "the great divide" of 1920, it becomes possible to see whether or how the Nineteenth Amendment empowered black women, their families, and their communities. ${ }^{5}$

Extending the assessment of the Nineteenth Amendment past 1920 is key, for scholarship on woman suffrage, classic and current, details the importance of the Fourteenth and Fifteenth Amendments for the movement, but only up until 1875. The long-standing alliance of suffragists and abolitionists, a coalition born at Seneca Falls in 1848, fractured during the Reconstruction-era debates over voting rights when suffrage was extended to black men but not to women of any race. In 1869, the allies made their fateful split, 
with supporters of the pending Fifteenth Amendment, such as Ellen Frances Watkins Harper and Lucy Stone, moving forward through work in the American Woman Suffrage Association while opponents of the Amendment, such as Elizabeth Cady Stanton and Susan B. Anthony, directed their efforts through the rival National Woman Suffrage Association, protesting bitterly that the deal left them at the mercy of men less qualified than they. In 1875, the U.S. Supreme Court's decision in Minor v. Happersett ended the efforts of Anthony, Mary Ann Shadd Cary, and other "New Departure" suffragists to persuade the courts that because women were citizens under the meaning of the Fourteenth Amendment, the Fifteenth Amendment's protections also extended to women. After Minor v. Happersett, historical accounts go silent on the ongoing relevance of the Fourteenth and especially the Fifteenth Amendment for the woman suffrage movement. But though white suffragists abandoned the effort to use the Fourteenth and Fifteenth Amendments to gain voting rights for women, African American suffragists did not. For them, not only were black women's voting rights at stake, but also those of black men. ${ }^{6}$

As historians of African American women's experiences have pointed out, accounts of the woman suffrage struggle that marginalize southern black women not only downplay the rich experiences of these women but misdirect the broad suffrage narrative as well. An intersectional approach, by contrast, expressly acknowledges that race and sex are "all bound up together" and illuminates how black suffrage activists, together with their families, churches, and communities, pressed broad agendas for uplift and justice. If the woman suffrage story features the experiences of African American women as aspiring voters and anchors them in the context of their families and communities, both their story and the story must be rewritten: the Fourteenth and Fifteenth Amendments become at once a failed strategy for enfranchising white women and an important step toward suffrage for black women; the suffrage struggles of black women and men become connected; and the "century of struggle" continues long after the Nineteenth Amendment was ratified. ${ }^{7}$

The implications of the Fifteenth Amendment for woman suffrage were much on the minds of leading African American suffragists and many white supremacists who opposed them. Even as suffragists intensified their campaigns in the first and second decades of the twentieth century, some white supremacists worked to repeal the Fifteenth Amendment, trying to close the door once and for all to any path back to the ballot for black men. After 1910, as more states enacted woman suffrage and as momentum built for the federal amendment, black suffragists feared, and white supremacists hoped, that the failure of the Fifteenth Amendment to secure African American men's voting rights in the late nineteenth century foreshadowed the failure of a possible federal amendment to secure African American women's voting rights. Both black suffragists and white supremacists, it turned out, were largely correct. After ratification in 1920, when federal action imposed woman suffrage on the states of the Old Confederacy, the past proved to be prologue when black women went to the polls.

\section{“A RUNNING AGITATION": FIFTEENTH AMENDMENT CONTROVERSIES, $1900-1915$}

The broad disfranchisement of African American men in the Jim Crow South seemed quite secure by about 1910. By then, historian Michael Perman argues, the decades- 
long process of disfranchisement "had reached its conclusion." 8 Even so, the Fifteenth Amendment remained intensely controversial in the first two decades of the twentieth century, and white supremacists worked to shrink its protections further still and even to repeal it outright. Supporters of black women's suffrage fought simultaneously to acquire voting rights for women and to preserve and enforce the Fifteenth Amendment.

The Fourteenth and Fifteenth Amendments were the target of repeated efforts at repeal in the 1900s and 1910s. In 1904, the House of Representatives debated whether the amendments had been legally adopted at all and whether they should be repealed. Rep. Thomas W. Hardwick of Georgia, a protegé of Tom Watson, introduced resolutions to that effect. He explained his purpose in a speech on the floor of the House on January 27, 1904. "The Fourteenth and Fifteenth Amendments were adopted, if adopted at all, against the will of the majority of all the people in the Union, by trickery and treachery in the North and by force and violence in the South." His effort was stymied but other southern legislators, including Representative J. Thomas ("Cotton Tom") Heflin (D-AL) and Senators Ben Tillman (SC) and James K. Vardaman (MS), continued to argue for repeal, calling in 1911 for a plebiscite on the matter. In 1916, Rep. Thomas Sisson of Mississippi introduced a resolution to ask the Justice Department to bring to the Supreme Court a test case that would determine whether the Fourteenth and Fifteenth Amendments were "legally adopted and are a part of the Constitution," or, as some white supremacist lawyers and lawmakers suspected, adopted in violation of other constitutional provisions. ${ }^{9}$

These repeal efforts came to naught but they were not to be dismissed, for they gained support outside the South and they were part of a broad reconsideration of voting rights in the late nineteenth- and early twentieth-century United States. New York, in fact, did rescind its ratification of the Fifteenth Amendment in 1870 when State Senator William "Boss" Tweed took advantage of new Democratic majorities in both houses in Albany to reduce the voting strength of Republicans by reducing the number of black voters. But black suffragists did not have to look back to 1870 to see threats to the continued survival of the Fifteenth Amendment, even in its attenuated state. White supremacists took to the hustings to spread their view that "an ignorant enfranchised Negro population" was a danger not only to the South, but to the nation. In 1900, when progressive child labor reformer Rev. Edgar Murphy of Alabama joined speakers from Georgia and North Carolina to lecture in Philadelphia on "The American Negro," writer Gertrude Bustill Mossell sounded the alarm at what she heard. Mossell was a journalist, clubwoman, and suffragist, the proud and politically active descendent of a Philadelphia African American family whose freedom predated the American Revolution. Murphy and his colleagues, she charged, had traveled to the very "cradle of liberty" to attack black political rights. "These men want the 15th Amendment repealed[;] they want to be placed in a position to rule without the disgrace of shooting the Negro." The next year, the Brooklyn Eagle called for the repeal of the Fourteenth and Fifteenth Amendments, arguing that the preservation of "government and civilization" required allegiance to a "higher constitution than the Federal compact." The debate over the legitimacy of black voting rights continued as T. Thomas Fortune's New York Age in 1911 criticized the "running agitation for repeal of the Fifteenth Amendment" by both members of Congress and clergymen of note, among them Dr. William Hayne Leavell, a founder of Rice University and soon President Woodrow Wilson's ambassador to Guatemala. Concerned that the upcoming elections might put then-Governor Wilson in the White House and Democratic majorities in both 
houses of Congress, the Age argued that African Americans had ample reason to worry. If Democrats had a good year in 1912, "the Negroes would be justified in expecting the most radical legislation in opposition to their civil and political rights guaranteed them by the Fourteenth and Fifteenth Amendments." 10

The broader political culture did not augur well, for African American men were not the only persons to lose their voting rights in the period. Despite poll tax exemptions for veterans and "grandfather" clauses designed to preserve ballot access for white men loyal to the Democratic Party, many of the devices that disfranchised African American men in the South disfranchised white men there as well. Poll taxes and literacy tests also tripped up white men who could not pay the tax or pass the test. Outside the South, progressive reformers hoped to "purify" the electorate by eliminating "problem voters," often targeting immigrants, ethnics, and urban workers as corrupt and unfit. Michigan and Wyoming repealed alien suffrage first, and by the early 1920s, all thirty-one states that had once permitted noncitizens to vote had rescinded it. States extended their residency requirements; at the extreme, Rhode Island required voters to establish residency by living not just in the state but in the locality for two years. Washington, Oregon, California, Wyoming, Arizona, Oklahoma, Delaware, New York, Connecticut, Massachusetts, New Hampshire, and Maine_-none of which belonged to the Old Confederacy - all instituted literacy tests. By the end of the 1920s, forty-six states required at least part of their voting population to register. Approximately a third of states limited the period for voter registration to a week or less. Personal registration procedures burdened prospective voters with the task of repeatedly presenting themselves to registrars. At the turn of the century, states from every region reshaped their electorates to make them more white, more middle class, and more likely native born. For African Americans working to expand voting rights, the national climate offered little encouragement. ${ }^{11}$

The controversies over the Fifteenth Amendment made their way to the Supreme Court, which in 1915 reaffirmed a cramped interpretation of the amendment's capacity. In Guinn and Beal v. United States, the court both threw out the "grandfather" clause as a disfranchising tool available to states and confirmed that literacy tests passed constitutional muster. At issue was an amendment to Oklahoma's 1910 state constitution that imposed both restrictions. The court rejected the grandfather clause as a "repugnant" and "open repudiation of the Fifteenth Amendment." Oklahoma's amendment, however, entangled the literacy test in the grandfather clause and the court declared both provisions void, but then expressly clarified that literacy tests complied with the amendment's requirements. Chief Justice Edward Douglass White delivered the court's opinion and declared that the literacy test requirement "was but the exercise by the State of a lawful power vested in it not subject to our supervision, and, indeed, its validity is admitted." The Guinn decision, often celebrated as a step forward for voting rights, surely also offered comfort to white supremacists by endorsing literacy tests as a restrictive device and affirming that the Fifteenth Amendment did not "change, modify or deprive the States of their full power as to suffrage."12

The Fifteenth Amendment's very existence was endangered just as the woman suffrage campaigns gained momentum, and African American suffragists took up both causes at once. Gertrude Mossell wrote in support of woman suffrage at least as early as 1885, echoing in the pages of the New York Freeman John Stuart Mill's sentiment that "the legal subordination of one sex to the other [is] wrong." Fifteen years later, 
she used her pen to decry black men's disfranchisement, and when she wrote about black men's voting rights, she meant "us." For Mossell, as for other African Americans of the day, ballots communicated not just individual voter's choice but also the broader community's will. "Now, if our colored men don't get united and ... look after the race interests they will wake up some fine day and witness the repeal of the 15th Amendment. We," she continued, including herself, though the Fifteenth Amendment had enfranchised only black men, "have had the ballot and lost it several times before in certain States. Now we have it nationally; but the South is a unit to disfranchise us and the crusade is now begun in Philadelphia, the cradle of liberty, to take it away practically forever." Mossell rejected silence, for "silence gives consent." 13

Adella Hunt Logan shared her concern. The Sparta, Georgia, native and Tuskegee Institute professor had joined the National American Woman Suffrage Association as early as 1895. Ten years later, she laid out an erudite rationale for black women's suffrage in The Colored American Magazine, a leading forum for discussion of public issues by the nation's African American elite. "After more than thirty years of trial some statesmen, real and pseudo, have concluded that the Fourteenth Amendment was a mistake," Logan began. All the same, the Fourteenth Amendment remained on the books, and the Amendment clearly stated that "all persons born or naturalized in the U.S. ... are citizens of the U.S. and of the states in which they reside." Logan continued in a blistering tone. "In the ordinary affairs of life women are regarded as persons. Why not treat them as such in questions of government? No, they are classed with" individuals deemed unfit to govern themselves or others- “minors, idiots, and paupers." Logan turned to Blackstone's Commentaries on the Laws of England, the authoritative treatise on English common law, and opined that "the writer knows women, some colored women, who claim and crave the sovereignty of full citizenship." Viewing the problem through an intersectional lens, Logan argued that African Americans, both women and men, needed the ballot even more urgently than the white Americans who already enjoyed it. "If white American women, with all their natural and acquired advantages, need the ballot, that right protective of all other rights; if Anglo Saxons have been helped by it—and they have-how much more do Black Americans, male and female, need the strong defense of a vote to help secure their right to life, liberty and the pursuit of happiness?"14

By 1915, Mary Church Terrell was the honorary past president of the National Association of Colored Women, the powerful reform organization that she had helped to found in 1896. Terrell unpacked the relationship between black women's suffrage campaigns, the endangered Fifteenth Amendment, and voting rights for black men in an article she wrote for W. E. B. DuBois's The Crisis. African American men, she argued, knew all too well the "yoke of oppression" of discrimination and injustice, and she called upon them to put their full weight behind efforts to enfranchise African American women.

Even if I believed that women should be denied the right of suffrage, wild horses could not drag such an admission from my pen or lips, for this reason: precisely the same arguments used to prove the ballot be withheld from women are advanced to prove that colored men should not be allowed to vote. The reasons for repealing the Fifteenth Amendment differ but little from the arguments advanced by those who oppose the enfranchisement of women. ${ }^{15}$

For Terrell and other African American suffragists, saving the Fifteenth Amendment and extending the vote to women were two fronts in the same fight. 
A RETURN TO “NEGRO RULE"?: AFRICAN AMERICAN VOTING RIGHTS AND THE PUSH FOR A FEDERAL SUFFRAGE AMENDMENT, 1915-1920

A series of states granted women the vote in the 1910s and as momentum built for a federal amendment, the Fifteenth Amendment and black men's voting rights loomed large in the public debate. The 1913 Washington, D.C., suffrage parade organized by Alice Paul and Lucy Burns for Woodrow Wilson's first inaugural returned the federal amendment to the nation's political agenda, and the House of Representatives took it up for debate for the first time in the new century. Returning President Carrie Chapman Catt committed NAWSA in 1916 to a secret "Winning Plan" that leveraged state-level victories to build support for a federal amendment. Since no state in the former Confederacy had yet granted women even partial suffrage, the only plausible route to the ballot for southern women, African American or white, was through a federal amendment. As supporters of black woman suffrage continued to call for the enforcement of the Fifteenth Amendment, white supremacists on both sides of the woman suffrage question debated whether a federal amendment would threaten white privilege. Their arguments, yea or nay, pivoted on their views of what the history of the Fifteenth Amendment predicted for black women's future voting rights.

Some white supremacist opponents of a federal amendment predicted doom if the Susan B. Anthony Amendment ever made it onto the books. The disfranchising work of two generations would be thrown into question, the whole "settlement" of the race question undone. The editors of the Richmond Evening Journal issued such a warning in 1915, arguing that woman suffrage would return "negro rule" to many Virginia counties, and that the white men of the Commonwealth would be duty-bound to again defend white supremacy through unsavory means, and thus "return to the slimepit from which we dug ourselves." When NAWSA embraced a federal strategy, Louisiana suffragist Kate Gordon founded the Southern States Woman Suffrage Conference and dedicated it to suffrage by state action. Gordon condemned the proposed Anthony Amendment as a "sequel" to the hated Fifteenth. Laura Clay, long the power behind the Kentucky Equal Rights Association, predicted that southern states would never accept woman suffrage if, like black men's suffrage, it was imposed by a federal amendment. The "Anthony Amendment," she declaimed at an emergency strategy meeting of NAWSA in 1916, was "a repetition of the Fifteenth Amendment." Reasonable people, she argued, could hardly expect southern states to "subscribe voluntarily to a principle they rejected formerly." 16

Historian Marjorie Spruill Wheeler argues that few Southerners of the day truly believed that a federal amendment would seriously threaten white supremacy. "Most suffragists," she writes in New Women of the New South, "believed the disfranchisement movement had successfully resolved 'the negro problem' and that the South did not need to fear further northern intervention on behalf of southern blacks." Emmet O'Neal, a jurist who had served as a delegate to Alabama's 1901 disfranchising constitutional convention, seemed to agree. O'Neal ardently opposed the impending federal amendment as "unwise, useless, and harmful," and yet recognized that it would no more guarantee suffrage for women than the Fifteenth Amendment had guaranteed suffrage for African American men. By the time he wrote in early 1920 as a retired governor, he compared the two amendments, noted that the latter one faithfully echoed the former, and concluded that the woman suffrage amendment gave no cause for concern. "Does the Anthony Amendment, if ratified, give to 
women the right of suffrage? The same question was asked as to the Fifteenth Amendment; and the same answer of the Supreme Court that it did not in its true sense give to the negroes the right of suffrage, would be the answer now, as to the Anthony Amendment."17

Indeed, a number of Southern suffragists were so confident of the power of states to disfranchise that they supported the Anthony Amendment with no fear that it would endanger white supremacy. Even if the federal amendment passed, they argued, states could use their powers, enshrined in the Fifteenth Amendment, to restrict access to the ballot by other means. Alabama suffragist Pattie Ruffner Jacobs of Birmingham had once supported suffrage by state action, but in 1915 she testified before the U.S. Senate that, should the federal amendment pass, states could take measures to ensure that only the "best" women and men, whether white or black, could exercise the vote. In 1918, NAWSA leader Ida Husted Harper tried to reach out to Kate Gordon and other states' rights suffragists who were unhappy with NAWSA's commitment to federal action by arguing that a federal amendment would not re-enfranchise African American men. Gordon was not convinced, but Lila Meade Valentine changed her mind. Valentine, president of Virginia's Equal Suffrage League, also had once called for suffrage by state action but by 1918 she had embraced the federal amendment. Opponents of woman suffrage, Valentine said, "conjur[ed] up the negro bogey," but the Virginia constitution of 1902 provided more than adequate means for preventing African Americans from exercising a majority. ${ }^{18}$

As two southern states broke rank and enacted partial suffrage provisions by state action, white supremacists began to demonstrate that white supremacy could withstand woman suffrage. Arkansas granted women the ability to vote in primary elections in 1917 and Texas followed the next year, but African American women encountered barriers there when they tried to cast votes. In Waco, Texas, for example, African American women and men together tried to vote in the July 1918 Democratic primary, only to be turned away by election officials. R.H. Hines wrote the NAACP headquarters in New York to bring the violation to the organization's attention. "We were prohibited from having any part in this election," Hines reported. "Our women were properly registered, and every requirement fulfilled." 19

The debate over the consequences of a future federal amendment ended when Tennessee ratified in August 1920. The Anthony Amendment became the Nineteenth Amendment and African American newspapers cheered the news. "Women Celebrate in Honor of Vote Right," the New York Age announced in a page-one headline. But southern state legislators were little more enthusiastic about woman suffrage than before. Kentucky, Texas, Arkansas, and Tennessee ratified, but Virginia and Mississippi rejected the amendment outright, Mississippi's legislators putting an exclamation point on the matter by voting to reject on election day, the very day that women elsewhere were casting their first votes. Women in Mississippi and Georgia missed the fall elections because their state legislatures failed to meet to waive poll taxes for women; poll tax payments had been due the previous winter, months before women had even gained the vote, and these states declined to provide an accommodation. The governor of Florida did call the legislature into session, but only after a member of the state's Supreme Court warned him that failure to do so might trigger the federal government to act on the Nineteenth Amendment's enforcement clause, and maybe the Fifteenth Amendment's, too. ${ }^{20}$

Kate Gordon, ever the states' rights loyalist, remained unreconciled to federal action even after the bitter end. In 1923, she sulked in a letter to her friend, Laura Clay. 
"Ratification by Tenn. was as fraudulent as the spirit that put over the 15th Amendment." But black suffragists shared none of her objections, and African American women in the South were determined to use their hard-won rights. ${ }^{21}$

\section{"SHE HAD LEARNED THE FIFTEENTH AMENDMENT BY HEART": SOUTHERN AFRICAN AMERICAN WOMEN'S STRUGGLES TO VOTE AFTER RATIFICATION}

The ratification of the Nineteenth Amendment pried open a crack in the edifice of white supremacy, putting the weight of the Constitution behind southern black voters for the first time in a generation. In the fall of 1920, newly enfranchised southern black women surged to the polls to press their claim that the Nineteenth Amendment included them. Black men joined them-husbands, fathers, brothers, and neighbors, some of them new veterans with proud records of service to country-with renewed determination to reclaim their voting rights. That fall and in the decade to come, some southern African Americans in fact succeeded in registering and casting ballots. Many, however, encountered a situation all too reminiscent of the disfranchisement period of the late nineteenth century: obstructionist tactics, threats, and sometimes violence as white supremacists worked to put down this fresh challenge to their power. And when black women encountered these barriers to the exercise of their new rights, they complained that, just like the Fifteenth Amendment before it, the Nineteenth Amendment was being ignored. ${ }^{22}$

In the fall of 1920, African American women in at least seven southern states succeeded in registering and voting. In Charles County, Maryland, about 160 black women-and nearly ninety black men-registered as Republicans during September. In Richmond, Virginia, about a tenth of the city's black women of voting age got themselves on the books. In North Carolina, perhaps a thousand African American women, scattered from the mountains in Asheville to the coastal region near New Bern, added themselves to the registration rolls. In Georgia, a Chatham County newspaper reported that "an astonishingly large number of negro women-more than 1,000"- - had gotten themselves registered in the Savannah area. In Atlanta, black women "in every ward in the city" turned out at the polls on election day. In Duval County, Florida, home to Jacksonville, some 6,400 African American women registered. Activists and news organizations from Birmingham and Mobile, Alabama and Houston, Texas, also reported major efforts to organize black women as voters. ${ }^{23}$

White supremacists may have regarded these efforts as threatening because when black women turned out to register and vote, they frequently brought the community with them. Spouses, other family members, pastors, neighbors, coworkers, and friends often accompanied aspiring women voters and lent crucial support. Historian Elsa Barkley Brown and others found that, during and after Reconstruction, African American men frequently brought their families and neighbors to the polls with them; in the 1920s, the company was just as welcome. The witness of others provided a certain safety in numbers, and the presence of "respectable" associates might induce unfriendly officials to treat these women with courtesy. Moreover, the presence of a group enacted the idea, also with a long history in African American communities, that the ballot expressed not just the will of the individual voter but rather the interest of the community at large. Above all, the people who joined these women often intended to register and vote themselves. ${ }^{24}$ 
Texas club woman and NAACP leader Christia Adair found that numbers could not assure success. She accompanied other activist friends to cast ballots in Kingsville, Texas, in 1918, but poll workers turned them away despite the new law enfranchising women in the state's Democratic primary elections. Adair recalled that her friend, Kitty Simmons, asked point-blank, "Are you saying that we can't vote because we're Negroes?" The election official provided an equally blunt answer: "Yes." Elsewhere, African American women who approached election officials in concert with others enjoyed greater success. In Baltimore in the fall of 1920, three residents of the "Old Folks Home" of the Methodist Episcopal Church registered together-Mrs. Mary Garrett, age ninety; and Mrs. Geneva Gray, age eighty-four, who "in clear voice but with shaking hands got themselves on the books"; and the ninety-year-old Mr. Moses James. In Atlanta, African American men "accompanied the women as they demanded the right to vote." Men who possessed experience in politics also schooled women on how to use their new right. In Lake City, Florida, an African American man and Republican loyalist organized women at "churches, lodges, and night schools" and conducted "meetings to instruct Negro women how to vote." Coworkers likewise lent support. When nine women from the faculty of the Virginia Normal and Industrial Institute in Petersburg, Virginia successfully registered, they marked the occasion by taking a group photo (see Figure 1). ${ }^{25}$

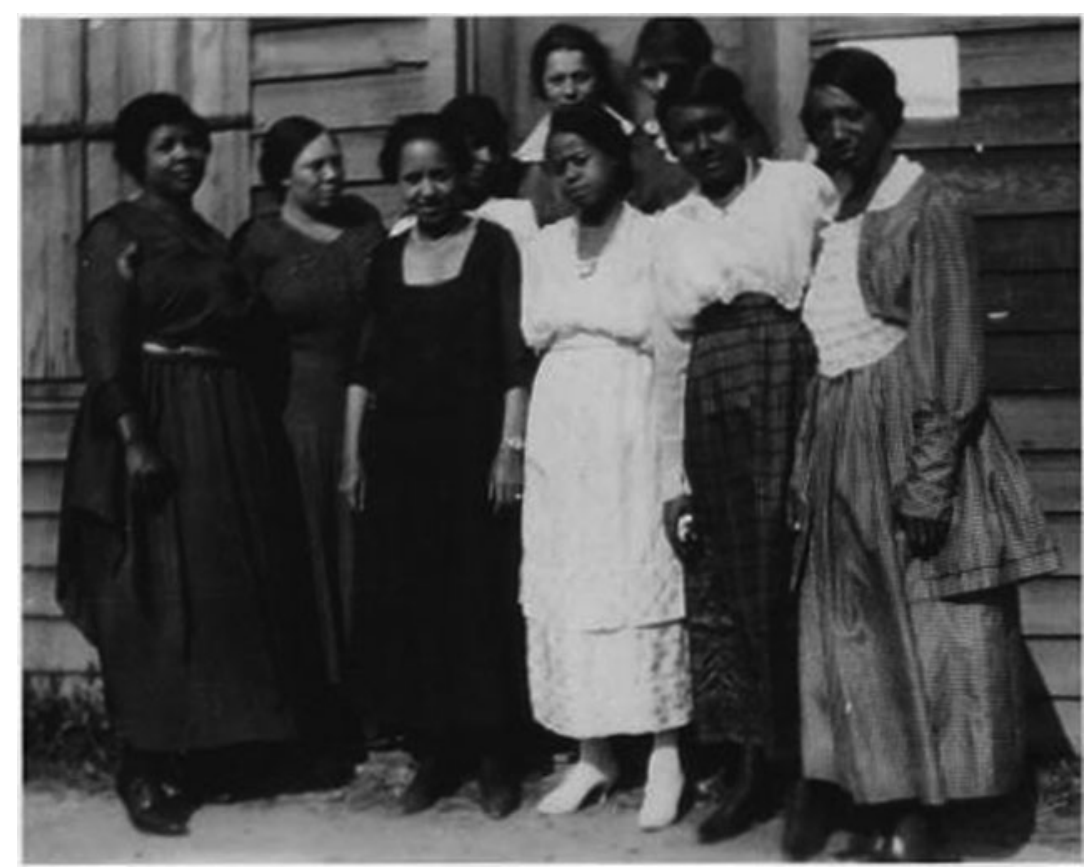

FIGURE 1. First female voters, Ettrick, Virginia, c. 1920.

Front row: Mary Branch, Anna Lindsay, Edna Colson, Edwina Wright, Johnella Frazer (Jackson), Nannie Nichols. Back row: Eva Conner, Evie Carpenter (Spencer), Odelle Green.

From the Evie Spencer DeCosta Papers, Special Collections and Archives, Johnston Memorial Library, Virginia State University, Petersburg, Virginia. 
Even with support, however, women's efforts to register and vote often failed as white elections officials defrauded black women with a wide range of disfranchising techniques. In Richmond, Virginia, registrars turned away women who brought "friends" with them "to help fill out forms." In Shreveport, Louisiana, resident T.G. Garrett reported to the NAACP that "six hundred of our most learned race women of Caddo Parish" turned up to register; of these, only four succeeded-three on account of "thair propity" and one "under the edicational test (sic)." The educational and professional attainments of some of the women denied, however, gave the lie to blanket claims that African American women were unqualified, a scenario that played out clearly in Tidewater Virginia. Lucile Wheelock, a college graduate and Hampton public school teacher, reported that the registrar quizzed her for nearly "three quarters of an hour" before telling her that she had failed. In Alabama, a county registrar recounted years later to political scientist Ralph Bunche how his office worked to discourage African American women who tried to register. "Way back in 1920," the registrar recalled, "we had a world of $\mathrm{n}^{*}$ women coming in to register. There was a dozen of them, I reckon, come in one registration period. We registered a few of them and then we put them off ... tell them they had to bring in white witnesses. ... Tell them how much poll tax it was going to cost them." In Americus, Georgia, election officials were reduced to a ridiculous game of cat-andmouse: when African American women approached, the registrar "would hide the book or himself." In Muskogee, Oklahoma, when black women showed up at the elections office, the panicked registrar promptly resigned. ${ }^{26}$

Obstructionist tactics, however, did not always dissuade the aspiring women, and when it failed, white supremacists resorted to intimidation and violence, much as they had during and after Reconstruction to prevent black men from voting. The black registration in Jacksonville, Florida, swelled in the fall of 1920, and newspapers reported that African American women accounted for a narrow majority of the new female registrants. A Republican campaign official complained to a U.S. senator that white supremacists sprang into action to scare the new registrants away from the polls. A thousand members of a "revived" Klan paraded the streets of Jacksonville "in disguise" on the night of October 30, 1920 - just days after the end of the registration period, and days before the election. Despite the effort to intimidate, more than four thousand registered African Americans showed up at the polls where, according to a subsequent NAACP investigation, they were turned away. Election day in Jacksonville passed without major violence, to the relief of observers in the local and national press, but such threats could not be ignored. One hundred fifty miles away, in Ococee, Florida, a black community was burned to the ground, its residents killed or permanently dispersed in an election-day pogrom triggered by a lone African American man's attempt to vote. And one year earlier, Jacksonville itself had been the site of the lynching of two black hack drivers. ${ }^{27}$

Lula Murry did not give up, and she did not fight alone. Her 1923 appeal was one of a raft of letters written by honorably discharged black veterans and their family members from the Birmingham area asking the president to enforce their constitutional voting rights. Arthur Ivey, who worked in the mid-1920s as a gardener, introduced himself to the president as a veteran who had "served in the U.S.A. Army." Indeed, service records indicate that he served in France in the 324th Service Battalion in a company that did forestry work, possibly clearing trees and building fortifications. Back home, he wrote to bring the violation of his rights to the president's attention. "I am denied 
the rights and privilege of a citizen which is due me in Article XIV and XV of the Constitution of the U.S.A." "My voting certificate," he continued " ... was denied me on these conditions. We are segregated on account of race and Color and the Constitution forbids anyone being segregated on account of race or color." 28

Letters by Ivey, Murry, and others in fact reached the White House, where President Coolidge's secretary, Bascom Slemp, referred them in routine fashion to the Justice Department. Dissatisfied, the activists continued to mobilize family and neighborhood ties to push for black access to the ballot box. In December 1925 they chartered their organization as the Ex-Soldiers Co-Operative Association. The association "was composed of several hundred colored members who had been in the last worlds war, were discharged honorably, paid, bonused and made poll-tax free for life." Now they had a "National Board of Directors," a headquarters in Birmingham's New Masonic Building, and officers, including Lula Murry, who served on the executive committee as a "Committeeman." From that point forward, they put their demands for justice on official organization letterhead. They sent a fresh wave of letters in early 1926, but this time, instead of making general appeals to constitutional justice, they named the Jefferson County Board of Registrars and its chairman, L. K. Bowen, as the proponents of a "conspiracy. To violate the Constitution of the U.S.A." Murry divulged only a few details of their most recent troubling encounter. The registrar prevented them from entering the building, instead requiring them to "make application on the outside doors," and then "turned down" every applicant. There was more to the story, but at this point Murry declined to go further. "If the whole detail upon the merits of this subject was explained[,] this sheet of paper could not hold the wordings." Within a matter of days, seventeen other members of the association sent similar letters, each writer backing up his or her claim to the ballot by recalling their sacrifice and service during World War I. "I am a sister of a deceased Ex-Soldier," Murry insisted. The association followed up in February with a formal, notarized petition to President Coolidge with fifteen signatories asking for an investigation of Alabama's compliance with the Fourteenth, Fifteenth, and Nineteenth Amendments and reasserting that "we stand ready to defend our Country upon any patriotic call, as in the past, with particular reference to the World's War." The petitioners included Birmingham neighbors Gus and Alice Stewart, husband and wife, and Murry's brothers, Jim and Ozie McNab. ${ }^{29}$

The Ex-Soldiers Co-Operative Association got its investigation. In January 1926, the FBI interviewed Murry and the group's secretary, Jerry S. Merriweather, who worked in the late 1920 s as an insurance agent. In the meeting at the association's Birmingham headquarters, Merriweather testified on behalf of the group that "despite the 15th Article of the Constitution they were hampered at the time of registration" and that though they had fulfilled every requirement and met "all the qualifications" for voting, repeating the process over a series of years, the registrar had failed to add their names to the rolls. Murry added that, in last year's attempt, "she had learned the 15th Amendment by heart" and recited it to the registrar, to no avail. ${ }^{30}$

The investigator was unimpressed. He found that though Murry and Merriweather were "above the average[,]"-more an insult than a compliment- "they are trouble makers in exciting the mass of colored people to vote." Some African Americans, he maintained, had successfully registered in the city, and most who had registered had not bothered to cast ballots. Alabama law, he noted, even provided the opportunity for 
anyone who was turned down to appeal. In the end, he concluded that the Board of Registrars had acted properly: "Investigation shows attempts to register, but qualifications not considered satisfactory to the registering officer."31

The U.S. attorney for the northern district of Alabama, C. B. Kennemer, was more sympathetic to the petitioners than the investigating agent had been. He reported back to Washington that Alabama law gave registrars "wide discretion and power." "I have absolutely no doubt," Kennemer wrote to Attorney General John G. Sargent, "and in fact I practically know, that such power and discretion is very frequently exercised in a highly biased and unfair manner." Even so, Kennemer concluded that the actions of the registrars were legal and that his office had no recourse. "I know of no action this office could take," Kennemer maintained, "that would in any manner be calculated to rectify such practices." The federal government would take no action to enfranchise Lula Murry or any other black woman in the Jim Crow South. And, much as African American men had found over time that the Fifteenth Amendment failed to secure their voting rights, African American women were learning that the Nineteenth Amendment would also fail them. ${ }^{32}$

In 1921, a year after ratification, Mary Church Terrell addressed the nation's black clubwomen through the pages of National Notes, the organ of the National Association of Colored Women's Clubs. Her advice to African American women on how to "Do Their Duty in Politics" reflected the troubling experience of the campaign season of the previous year. Terrell gave advice on voting - on casting informed ballots in order to put "good men into office and [keep] bad men out"-and castigated any black women who could vote but failed to "cast their ballots for men who will uphold the Constitution of the United States, and who stand for justice and fair play to all." Women who could vote but did not, or did not vote intelligently, "perpetuate an irreparable injustice upon their race." But Terrell also realized that many of her readers were still disfranchised and that they, more than ever, needed to participate in politics in whatever ways they could. In the last election cycle, Terrell recalled, "I realized more than I had ever done before that situations, methods, and conditions confronting colored women [vary] materially in the various States." Women who lived "in those sections of the country where the Fifteenth Amendment is not violated" had plenty of work to do. Terrell left unspoken the obvious implication of her words - that the Fifteenth Amendment was being violated in some states-and instead spelled out ways that disfranchised women could still influence politics. "If they believe a certain man will deal justly by their race, they might go to him and urge him to become a candidate." Staying abreast of legislative activity and writing letters to representatives was also a "powerful weapon of defense." Colored women, she argued, "should actively engage in politics wherever, whenever, and however they can without actually breaking the law." 33

In 1921, it should not have been necessary for Terrell to list ways black women could participate in politics if they could not vote. Her words, however tactful, contained a bitter recognition that the Nineteenth Amendment was also being "violated," and that the failure of the Fifteenth Amendment to enfranchise the mass of black men had in effect functioned as a rehearsal for the disfranchisement of black women after the ratification of the Nineteenth Amendment. Some of those "violations" echoed the disfranchising techniques 
of the past - the chicanery, the poll taxes, the literacy tests, the resort to intimidation and violence. But thanks to Terrell, Lula Murry, Arthur Ivey, and many others, aspiring black voters would generate so much political pressure in early years after ratification that white supremacists would be compelled to search for other ways to block them. When white supremacists expanded the white primary system to more efficiently disfranchise black women and men, they opened up a path to Smith v. Allwright and the 1965 Voting Rights Act that aspiring black voters would use to bring the promise of the Fifteenth and Nineteenth Amendments closer to fulfillment. ${ }^{34}$

Closer, but not fulfilled-not even today. In today's historical moment-2018African American voting rights remain endangered. Certainly, modern-day techniques for using ostensibly race-neutral election procedures to disfranchise in racially disparate ways draw from the "old playbook" established during and after Reconstruction. Today's use of restrictive voter ID laws to prevent "fraud," for example, echo concerns about fraudulent black votes during the period white supremacists falsely dubbed "Negro Rule." Modern gerrymandering reduces the power of black votes much like the shift to at-large electoral districts did in Progressive Era cities.

But as these disfranchising techniques proceed under the fiction of race neutrality, a more fundamental challenge to black voting rights has resurfaced in public discourse, one that, one might think, an enlightened, post-Voting Rights Act nation had put to rest. ${ }^{35}$ In November 2017, when CNN aired Republican Senate candidate Roy Moore remarked that getting rid of constitutional amendments after the Tenth would "eliminate many problems," He gave fresh voice to the century-old argument that the Fourteenth and Fifteenth Amendments were a bad idea, and maybe never even properly ratified to begin with. ${ }^{36}$ Old arguments over the legitimacy of voting by African Americans still echo in public discourse today. "A running agitation?" Indeed.

\section{NOTES}

${ }^{1}$ Lula Murry to Hon. Calvin Collidge [sic], Oct. 17, 1923, RG 60, Classified Subject Files, Correspondence, Department of Justice Central Files (hereafter "DOJ Files"), Archives II, College Park, MD. My thanks to Laura Edwards, Mia Bay, and the anonymous readers at JGAPE for their helpful comments. This research was supported by the National Endowment for the Humanities and Wayne State University Office of the Provost and Humanities Center. An earlier version of this work was presented at the McNeil Center for Early American Studies 2017 symposium on "Emancipations, Reconstructions, and Revolutions: African American Politics in the Long 19th Century."

${ }^{2}$ On the substantial numbers of women, including but not limited to black women, who remained disfranchised after 1920, see Liette Gidlow, "Resistance after Ratification: The Nineteenth Amendment, African American Women, and the Problem of Female Disfranchisement after 1920," Women and Social Movements in the U.S., 1600-2000 (hereafter "WASM") 21 (Mar. 2017), available at http://womhist.alexanderstreet. com/index.htm.

${ }^{3}$ The 90 percent figure comes from Eric Foner, Reconstruction: America's Unfinished Revolution, 18631877 (New York: HarperCollins, 1988), 291. On the Fourteenth and Fifteenth Amendments and black voting rights, see Charles H. Wesley, Negro Citizenship in the United States: The Fourteenth Amendment and the Negro-American, Its Concepts and Developments, 1868-1968 (Washington, DC: Association for the Study of Negro Life and History, 1968); Charles H. Wesley, The Fifteenth Amendment and Black America, 18701970 (Washington, DC: Associated Publishers, 1970); Laura F. Edwards, A Legal History of the Civil War and Reconstruction (New York: Cambridge University Press, 2015), esp. 105-10. On African American men's voting in the South during and after Reconstruction, see Steven Hahn, A Nation Under Our Feet: Black Political Struggles in the Rural South from Slavery to the Great Migration (Cambridge, MA: Harvard 
University Press, 2003); Thomas Holt, Black over White: Negro Political Leadership in South Carolina During Reconstruction (Urbana: University of Illinois Press, 1977), esp. 26-40.

${ }^{4}$ On the disfranchisement of African American men in the South, see Michael Perman, Struggle for Mastery: Disfranchisement in the South, 1888-1908 (Chapel Hill: University of North Carolina Press, 2001); J. Morgan Kousser, The Shaping of Southern Politics: Suffrage Restriction and the Establishment of the One-Party South (New Haven, CT: Yale University Press, 1974); Hahn, A Nation Under Our Feet, 366$67,442-50$.

${ }^{5}$ Nancy F. Cott, "Across the Great Divide: Women in Politics Before and After 1920" in Women, Politics, and Change, eds. Louise Tilly and Patricia Gurin (New York: Russell Sage Foundation, 1990), 153-76.

${ }^{6}$ Among the many accounts of the fracturing of the abolition/suffrage coalition and the consequences of that split over time, see Faye E. Dudden, Fighting Chance: The Struggle Over Woman Suffrage and Black Suffrage in Reconstruction America (New York: Oxford University Press, 2011); Rosalyn Terborg-Penn, African American Women in the Struggle for the Vote, 1850-1920 (Bloomington: Indiana University Press, 1998); Louise Newman, White Women's Rights: The Racial Origins of Feminism in the United States (New York: Oxford University Press, 1999); Eleanor Flexner, Century of Struggle: The Woman's Rights Movement in the United States (New York: Atheneum, 1974); Aileen S. Kraditor, The Ideas of the Woman Suffrage Movement, 1890-1920 (New York: Columbia University Press, 1965); Ellen Carol DuBois, Woman Suffrage and Women's Rights (New York: New York University Press, 1998); Lori D. Ginzberg, Elizabeth Cady Stanton: An American Life (New York: Hill and Wang, 2009).

${ }^{7}$ Martha S. Jones, All Bound up Together: The Woman Question in African American Public Culture, 1830-1900 (Chapel Hill: University of North Carolina Press, 2007); Terborg-Penn, African American Women in the Struggle for the Vote; Paula Giddings, When and Where I Enter: The Impact of Black Women on Race and Sex in America, reprint ed. (New York: HarperCollins, 1984; New York, Perennial, 2001), esp. chap. 9; Darlene Clark Hine and Kathleen Thompson, A Shining Thread of Hope: The History of Black Women in America (New York: Broadway Books, 1999), 165-239; Evelyn Brooks Higginbotham, Righteous Discontent: The Women's Movement in the Black Baptist Church, 1880-1920 (Cambridge, MA: Harvard University Press, 1993). An essential source are the many essays in Ann D. Gordon and Bettye Collier-Thomas, eds., African American Women and the Vote, 1837-1965 (Amherst: University of Massachusetts Press, 1997), especially Gordon, "Introduction"; Terborg-Penn, "African American Women and the Vote: An Overview"; Elsa Barkley Brown, "To Catch the Vision of Freedom: Reconstructing Southern Black Women's Political History, 1865-1880"; and Cynthia Neverdon-Morton, "Advancement of the Race through African American Women's Organizations in the South, 1895-1925."

${ }^{8}$ Perman, Struggle for Mastery, 319.

${ }^{9}$ John R. Vile, Encyclopedia of Constitutional Amendments, Proposed Amendments, and Amending Issues, 1789-1995 (Santa Barbara, CA: ABC-CLIO, 1996), 193-94; "Speech of Hon. Edward De V. Morrell, of Pennsylvania, in the House of Representatives, Monday, Apr. 4, 1904," Daniel Murray Pamphlet Collection, Library of Congress, Washington, DC, available at https://memory.loc.gov/cgi-bin/query/r?ammem/murray: @ field(DOCID+@lit(lcrbmrpt2609div0)): (accessed Dec. 1, 2016); editorial, "The Fifteenth Amendment," New York Age, Oct. 5, 1911, Tuskegee Institute News Clippings File (hereafter "TNCF") (Sanford, NC: Microfilming Corp. of America, 1976), reel 1, frame 300; Chicago Defender, Feb. 5, 1916. See also the editorial, "Again the Fifteenth Amendment," Elyria (OH) Telegram, July 14, 1917, TNCF, reel 6, frame 843.

${ }^{10}$ George William Curtis, "Can New York Withdraw Its Assent?," Harper's Weekly, Jan. 29, 1870, 66; Mrs. N. F. Mossell to editor, The Colored American, Mar. 24, 1900, 4, available at WASM (accessed Dec. 8, 2016); Brooklyn Eagle, quoted in Glenn Feldman, Politics, Society, and the Klan in Alabama, 19151949, 2nd ed. (Tuscaloosa: University of Alabama Press, 1999), 52; editorial, "The Fifteenth Amendment," New York Age, Oct. 5, 1911, TNCF.

${ }^{11}$ On efforts to disfranchise or reform diverse "problem voters," see Liette Gidlow, The Big Vote: Gender, Consumer Culture, and the Politics of Exclusion, 1890s-1920s (Baltimore: The Johns Hopkins University Press, 2004), 24-26, 37-39; Alexander Keyssar, The Right to Vote: The Contested History of Democracy in the United States (New York: Basic Books, 2000), Appendix Tables A.12, A. 13, A.14. On Oregon's racialized poll tax scheme, enacted in 1862 and applying the poll tax to "every 'negro, Chinaman, Kanaka, or mulatto' in the state," see Peggy Pascoe, What Comes Naturally: Law and the Making of Race in America (New York: Oxford University Press, 2009), 79.

${ }^{12} 238$ U.S. 347, 366, 362, available at https://www.law.cornell.edu/supremecourt/text/238/347 (accessed Nov. 21, 2016). 
${ }^{13}$ Mrs. N. F. Mossell, "Woman Suffrage," New York Freeman, Dec. 26, 1885, 2; Mossell to editor, The Colored American, Mar. 24, 1900, 4. On African American voting as an expression of the community's interest, see Brown, "To Catch the Vision of Freedom," 82-85.

${ }^{14}$ Adella Hunt Logan, "Woman Suffrage," The Colored American Magazine (Sept. 1905), 487, 489, available at https://babel.hathitrust.org/cgi/pt?id=uc1.b3793665; view=1up;seq=527 (accessed Dec. 28, 2016). On Logan, see Adele Logan Alexander, Homelands and Waterways: The American Journey of the Bond Family, 1846-1926 (New York: Pantheon Books, 1999), 310-16.

${ }^{15}$ Mary Church Terrell, "Woman Suffrage and the 15th Amendment," The Crisis 10, no. 4 (Aug. 1915): 191.

${ }^{16}$ Marjorie Spruill Wheeler, New Women of the New South: The Leaders of the Woman Suffrage Movement in the Southern States (New York: Oxford University Press, 1993), 128-29, 161.

${ }^{17}$ Wheeler, New Women of the New South, 143; Emmet O'Neal, "The Susan B. Anthony Amendment. Effect of Its Ratification on the Rights of the States to Regulate and Control Suffrage and Elections," Virginia Law Review 6, no. 5 (1920): 360, 344.

${ }^{18}$ Wheeler, New Women of the New South, 129-30, 169, 163.

${ }^{19}$ R. H. Hines to "Sec., N.A.A.C.P.," Sept. 18, 1918, Papers of the NAACP. Part 4, Voting Rights Campaign, 1916-1950, eds. August Meier and Martin Paul Schipper (Frederick, MD: University Publications of America, 1986).

${ }^{20}$ Jeannette Carter, "Women Celebrate in Honor of Vote Right," New York Age, Sept. 4, 1920, 1, available in WASM; Wheeler, New Women of the New South, 181.

${ }^{21}$ Wheeler, New Women of the New South, 177.

${ }^{22}$ For a fuller account of African American women's experiences as aspiring voters in the South in the fall of 1920, see Gidlow, "Resistance After Ratification." On activism by African American veterans of the First World War, see Chad L. Williams, Torchbearers of Democracy: African American Soldiers in World War I Era (Chapel Hill: University of North Carolina Press, 2010).

${ }^{23}$ Baltimore Morning Sun, Sept. 30, 1920, TNCF, reel 12, frame 189; Andrew Buni, The Negro in Virginia Politics, 1902-1965 (Charlottesville: University Press of Virginia, 1967), 79; Glenda Elizabeth Gilmore, Gender and Jim Crow: Women and the Politics of White Supremacy in North Carolina, 1896-1920 (Chapel Hill: University of North Carolina Press, 1996), 218-24; NAACP, "Disfranchisement of Colored Americans in the Presidential Election of 1920," [Dec. 1920], 14, 18, Box C285, Group I, Records of the National Association for the Advancement of Colored People (hereafter "NAACP Records"), Manuscript Division, Library of Congress, Washington, DC; Jacksonville Metropolis, Sept. 30, 1920, TNCF, reel 12, frame 189; Lorraine Gates Schuyler, The Weight of Their Votes: Southern Women and Political Leverage in the 1920s (Chapel Hill: University of North Carolina Press, 2006), 28-36; Nikki Brown, Private Politics and Public Voices: Black Women's Activism from World War I to the New Deal (Bloomington: Indiana University Press, 2006), 147-48.

${ }^{24}$ Brown, "To Catch the Vision of Freedom," 82-85. See also Jones, All Bound Up Together, 142-49; and Holt, Black Over White, 34-35. This sense of responsibility extended across regional lines. On "proxy voting" by African American women outside the South on behalf of disfranchised blacks in the South, see Lisa G. Materson, For the Freedom of Her Race: Black Women and Electoral Politics in Illinois, 1877-1932 (Chapel Hill: University of North Carolina Press, 2009), esp. chap. 2.

${ }^{25}$ Ruth Winegarten, ed., Black Texas Women: 150 Years of Trial and Triumph (Austin: University of Texas Press, 1995), 207; Baltimore Afro American, Sept. 24, 1920, TNCF, reel 12, frame 189; NAACP, "Disfranchisement," [Dec. 1920], 20, 12.

${ }^{26}$ NAACP, "Disfranchisement," [Dec. 1920], 19; T. G. Garrett to "The N.A.A.C.P.," Oct. 30, 1920, Group I, Box C284, NAACP Records; typescript, [Addie W. Hunton], "Phoebus” [Oct. 25, 1920], Box C284, Group I, NAACP Records; Ralph J. Bunche, "The Negro in the Political Life of the United States," Journal of Negro Education 10, no. 3 (1941): 571; S. S. Humbert to the NAACP, Nov. 9, 1920, Box C284, Group I, NAACP Records; [New York] News, Feb 27, 1919 [?], reel 20, frame 127, TNCF.

${ }^{27}$ [Alexander Akerman] to Sen. William C. Kenyon, Nov. 6, 1920; and Walter White to James C. Cobb, Dec. 10, 1920, both in Box C284, Group 1, NAACP Records; Jacksonville, FL Times-Union, Nov. 3, 1920, in Group 2, Box L265, NAACP Records. On the 1919 Jacksonville lynchings and the tense election season there in 1920, see Robert Cassanello, To Render Invisible: Jim Crow and Public Life in New South Jacksonville (Gainesville: University Press of Florida, 2013), 140, 145-49; and Paul Ortiz, Emancipation Betrayed: The Hidden History of Black Organizing and White Violence in Florida from Reconstruction to the Bloody Election of 1920 (Berkeley: University of California Press, 2005), 219-20.

${ }^{28}$ Arthur Ivey to Hon. Calvin Coolidge, Oct. 16, 1923, DOJ Files. 
${ }^{29}[$ Federal Bureau of Investigation (FBI)] Report, W. B. Poole, Atlanta, Georgia, Jan. 18, 1926, "SUBJECT, A Colored Woman," DOJ Files; "Declaration of Incorporation of Ex-Soldiers Co-Operative Association, Inc.," Dec. 11, 1925; Lula B. Murry to [U.S.] Department of Justice, [c. Jan. 6, 1926]; petition, Executive Representatives of the Ex-Soldiers Co-operative Association to the Honorable Calvin Coolidge, Feb. 1, 1926, all in DOJ Files.

${ }^{30}$ FBI Report, W. B. Poole, Jan. 18, 1926, DOJ Files.

${ }^{31}$ FBI Report, W. B. Poole, Jan. 18, 1926, DOJ Files.

${ }^{32}$ C. B. Kennemer to Attorney General, Jan. 20, 1926, DOJ Files.

${ }^{33}$ Mary Church Terrell, "An Appeal to Colored Women to Vote and Do Their Duty in Politics," [1921], available in WASM.

${ }^{34}$ On the expansion of the white primary as a response to the pressure created by black voters, women and men, after ratification of the Nineteenth Amendment, see Gidlow, "Resistance After Ratification."

${ }^{35}$ Liette Gidlow, "We Must Protect Voting Rights," Detroit News, Jan. 14, 2018, available at http://www. detroitnews.com/story/opinion/2018/01/14/voting-rights/109469068/ (accessed Jan. 17, 2018).

${ }^{36}$ Andrew Kaczynski, "Roy Moore in 2011: Getting Rid of Amendments After 10th Would 'Eliminate Many Problems." $C N N$, Dec. 12, 2017. Available at https://www.cnn.com/2017/12/10/politics/kfile-roymoore-aroostook-watchmen/index.html (accessed Feb. 12, 2018). 